\title{
Inhibition of nitric oxide synthase by nasal decongestants
}

\author{
G.J. Westerveld*, H-P. Voss**, R.M. van der Hee*, G.J.N. de Haan-Koelewijn**, \\ G.J.M. den Hartog ${ }^{*,+}$, R.A. Scheeren*, A. Bast ${ }^{+}$
}

Inhibition of nitric oxide synthase by nasal decongestants. G.J. Westerveld, H-P. Voss, R.M. van der Hee, G.J.N. de Haan-Koelewijn, G.J.M. den Hartog, R.A. Scheeren, A. Bast. (C) ERS Journals Ltd 2000.

ABSTRACT: The nasal decongestants oxymetazoline and xylometazoline are frequently used in the topical treatment of rhinitis and sinusitis. As nitric oxide (NO) is thought to play a role in inflammation of the upper respiratory tract, the aim of this study was to examine the in vitro effects of these compounds on the activity and the expression of NO producing enzymes, including the inducible form of NO synthase (iNOS) and the constitutive isoform of NO synthase (cNOS).

Experiments concerning the effects of both compounds on enzymatic activity and enzyme induction of iNOS were performed in a lipopolysaccharide (LPS) induced rat alveolar macrophage cell line (NR8383) using the Griess assay and the ${ }^{3} \mathrm{H}$-citrulline assay respectively. The effects on cNOS were examined in fresh rat synaptosomes using the ${ }^{3} \mathrm{H}$-citrulline assay. The direct scavenging properties of both compounds were investigated using a amperometric NO sensor.

Oxymetazoline and xylometazoline were shown to have a dose dependent inhibitory effect on total iNOS activity indicated by nitrite/nitrate formation in the Griess assay. This effect was found to be due to an inhibition of induction of the enzyme rather than inhibition of the enzyme activity, as was investigated in two separate experiments using the ${ }^{3} \mathrm{H}$-citrulline assay. Inhibition of cNOS was moderate and in the same order of magnitude as the inhibition of enzymatic iNOS activity. Direct scavenging of NO could not be detected.

As constitutive nitric oxide synthase activity is thought to serve beneficial physiological functions, and exaggerated inducible nitric oxide synthase activity may cause exacerbation of the inflammatory process, pharmacological treatment influencing the nitric oxide generating system should focus on inhibition of inducible nitric oxide synthase alone. The specific characteristics of these decongestants in vitro suggests suitability for this application and may indicate an additional beneficial effect in the treatment of upper respiratory tract inflammation.

Eur Respir J 2000; 16: 437-444.
*Dept of Otorhinolaryngology and Head and Neck Surgery, University Hospital Vrije Universiteit, Amsterdam, the Netherlands, ${ }^{* *}$ Leiden/Amsterdam Center for Drug Research, Dept of Pharmacochemistry, Vrije, Universiteit, Amsterdam, the Netherlands, 'Dept of Pharmacology and Toxicology, University of Maastricht, Maastricht, The Netherlands.

Correspondence: G.J. Westerveld, Department of Otorhinolaryngology and Head and Neck Surgery, University Hospital Vrije Universiteit, PO Box 7057, 1007 MB Amsterdam, The Netherlands. Fax: 31 204443688 .

Keywords: Macrophages nitric oxide synthase

$N$-nitro-L-arginine methylester oxymetazoline upper airway inflammation xylometazoline

Received: October 251999 Accepted after revision May 172000

This study was supported by grant 93.72 from the Netherlands Asthma Foundation, Leusden, the Netherlands.
Nitric oxide (NO) is a free radical that is known to have an important function as mediator in several biological processes amongst which, vasorelaxation [1, 2], cellmediated immune responses [3, 4], inhibition of platelet aggregation [5] and neurotransmission [6] are extensively investigated. The formation of NO has been described in many mammalian cell types and can be ascribed to three isoforms of nitric oxide synthase (NOS), all of which oxidize L-arginine to L-citrulline. The two constitutive forms of NOS (cNOS), which are $\mathrm{Ca}^{2+} /$ calmodulin dependent, are typically found in neural and vascular endothelial cells. Endothelial NOS is located on the cell membrane and releases NO for short periods of time in response to receptor or physical stimulation. Neuronal NOS has been identified in the cytosol of central and peripheral neurons [7]. The inducible form of NOS (iNOS), which is $\mathrm{Ca}^{2+}$-independent, can be found in inflammatory cells, such as macrophages, after they are activated by proinflammatory mediators like oxidants, cytokines and endotoxins. Once this enzyme is expressed it produces significantly larger amounts of $\mathrm{NO}$ for longer periods than the constitutive isoform does $[8,9]$. NO is known to play an important role in airway function and seems to be implicated in the pathophysiology of several lower airway diseases. Since there is an evident relationship between nasal inflammation and inflammatory pulmonary disease a role of $\mathrm{NO}$ in upper respiratory inflammations can be anticipated.

It has been reported that the levels of NO in exhaled air of patients with upper respiratory tract infections are increased $[10,11]$. It has also been shown that considerable levels of NO metabolites are present in nasal lavage fluid of patients with house dust mite allergy [12] and that nasal polyps contain higher levels of NOS than normal nasal mucosa [13]. In addition, the exact localization of NOS in nasal mucosa has been identified [14, 15]. Furthermore, NOS activity seems to be involved in nasal vascular conductance and in nasal cavity volume $[16,17]$. Also NO, upon reaction with the superoxide anion radical and forming peroxynitrite, has been shown to act as potent cytotoxic effector molecule [18]. Both features may contribute to nasal inflammation and 
indicate the involvement of $\mathrm{NO}$ in the pathogenesis of upper respiratory tract inflammation.

In upper airway inflammation, nasal decongestants such as oxymetazoline and xylometazoline, are frequently used in the topical treatment. Their effectiveness is thought to be due to direct $\alpha$-adrenergic receptor stimulation on the vascular smooth muscle in the nasal mucosa, leading to vasoconstriction. However, it is justified to presume that, in the clinically used concentrations, which are in the millimolar range, other molecular mechanisms play a role in the therapeutic effect. Recently the distinct antioxidant properties of oxymetazoline and xylometazoline i.e. hydroxyl radical scavenging and lipid peroxidation inhibition have been reported [19].

Presuming that the NO generating system is involved in the pathogenesis of upper respiratory tract inflammation, the effects of oxymetazoline and xylometazoline on activity and expression of cNOS and iNOS were determined in an in vitro model. In addition, possible NO scavenging properties were investigated.

\section{Materials and methods}

\section{Chemicals}

Roswell Park Memorial Institute (RPMI) 1640 medium, Ham's F-12 medium, glutamine and Fungibact were obtained from BioWhittaker (Walkersville, MD, USA). Foetal calf serum (FCS), $N$-2-hydroxyethylpiperazine- $N$-2ethanesulphonic acid (HEPES), tris hydroxymethyl-amino methane (Tris) and ethylene diamine tetracetic acid (EDTA) were purchased from Life Technologies (Paisley, UK). Dowex was obtained from ACROS (Geel, Belgium). Leupeptin, phenylmethylsulfonyl fluoride (PMSF), dithiothreitol, aprotin, lipopolysaccharide(LPS), reduced nicotinamide adenine dinucleotide phosphate (NADPH), L-arginine, $\mathrm{N}$ tris (hydroxymethyl)methyl-2-aminoethanesulphonic acid (TES), L-nitroarginine methyl ester (L-NAME), oxymetazolinexylometazoline, $N$-(1-naphtyl)ethylenediamine, sulphanylamide and 8-anilino-1-naphtalene-sulphonic acid were purchased from Sigma Chemicals Co. (St.Louis, MO, USA). Trypsin inhibitor from soybean was obtained from Difco Laboratories Inc. (Detroit, Michigan, USA). Sucrose and ethylene glycol tetra acetic acid (EGTA) were obtained from Merck (Darmstadt, Germany). Hydrogen peroxide was purchased from J.T. Baker (Deventer, Holland); [2,3,4,5]${ }^{3} \mathrm{H}$-l-arginine was obtained from Amersham International plc. (Little Chalfont, Buckinghamshire, UK). All other used chemicals were of reagent grade.

The macrophage cell line, NR8383 was kindly provided by R.J. Helmke, (Dept of Pediatrics, University of Texas Health Science Center, San Antonio, Texas, USA). Klebsiella Pneumoniae were a kind gift from J. van Amsterdam (Rijksinstituut voor Volksgezondheid en Milieu, Bilthoven, the Netherlands).

\section{Study design}

To determine the effects of oxymetazoline and xylometazoline on iNOS and cNOS experiments according to the diagram shown in figure 1 were conducted. iNOS was expressed in rat alveolar macrophages by adding LPS in

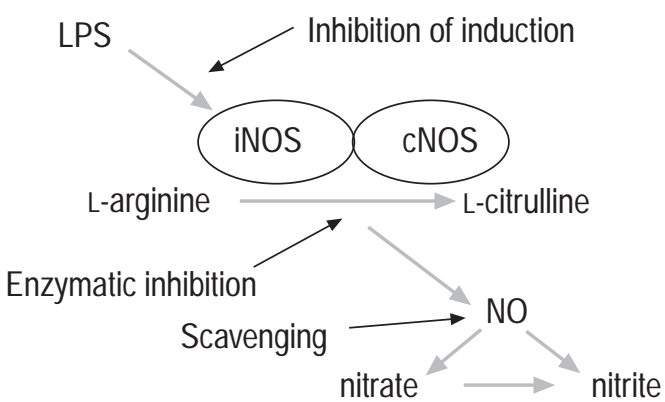

Fig. 1. - Study design. In order to establish the overall effect of oxymetazoline, xylometazoline and reference compound L-nitroarginine methyl ester (L-NAME) on the activity of lipopolysaccharide (LPS) induced nitric oxide synthase (iNOS), total nitrite production was measured first (Griess-assay). To separate the effects of the test compounds on induction, inhibition and enzymatic activity inhibition, the formed amount of radioactive $\mathrm{L}$-citrulline was measured in a second experiment $\left({ }^{3} \mathrm{H}\right.$-citrulline assay). In these experiments test compound was only added during LPS induction or during conversion of L-arginine to Lcitrulline. In addition the effects of the test compounds on constitutive nitric oxide synthase (cNOS) activity ( ${ }^{3} \mathrm{H}$-citrulline assay) and nitric oxide (NO) scavenging (amperometric NO sensor method) were investigated.

the presence and absence of the test compounds. Primarily the effects on total iNOS activity were measured by the formation of nitrate and nitrite, which was determined in the Griess-assay [20]. To elucidate the findings, a second set of experiments was performed using the ${ }^{3} \mathrm{H}$ citrulline assay [21], in which the conversion of tritiated $\mathrm{L}$-arginine to L-citrulline is measured. By adding the test compounds only during LPS induction or only after LPS induction, effects on enzyme induction and enzymatic activity respectively could be separated. In addition the effects of the test compounds on cNOS activity were examined, using the same ${ }^{3} \mathrm{H}$-citrulline assay. NO scavenging was investigated using a amperometric NO sensor.

All experiments were carried out in triplicate. Results are presented as mean \pm SD. The different parts of the experiments are described in more detail below.

\section{Cell culture and induction of nitric oxide synthase}

A rat pulmonary alveolar macrophage cell line, NR8383, was used as the source of iNOS [22, 23]. Cells were maintained in culture at a floating cell concentration of $10^{5}$ cells $\cdot \mathrm{mL}^{-1}$ in RPMI 1640 medium containing 2 $\mathrm{mM}$ glutamine, $0.5 \%$ Fungibact $\left(50 \mathrm{U} \cdot \mathrm{mL}^{-1}\right.$ penicillin, 50 $\mu \mathrm{g} \cdot \mathrm{mL}^{-1}$ streptomycin) and $10 \%$ heat inactivated FCS. Cells were grown in $162-\mathrm{cm}^{2}$ flasks (Costar Cambridge, MA, USA) in a humidified, $37^{\circ} \mathrm{C}, 5 \% \mathrm{CO}_{2}$ incubator. Cells were collected $(112 \times g, 1000$ revolutions per minute (rpm), Heraeus Labofuge $400 \mathrm{R}, 5 \mathrm{~min}, 25^{\circ} \mathrm{C}$ ) and resuspended at a cell concentration of $10^{6}$ cells $\cdot \mathrm{mL}^{-1}$ in Ham's F-12 medium containing $2 \mathrm{mM}$ glutamine and $0.5 \%$ Fungibact $\left(50 \mathrm{U} \cdot \mathrm{mL}^{-1}\right.$ penicillin, $50 \mu \mathrm{g} \cdot \mathrm{mL}^{-1}$ streptomycin). NOS was induced by addition of $10 \mu \mathrm{g}$ bacterial LPS $10^{6}$ cells $^{-1}$ with or without the test compounds oxymetazoline and xylometazoline in different concentrations. The samples were incubated during $24 \mathrm{~h}$ $\left(37^{\circ} \mathrm{C}, 5 \% \mathrm{CO}_{2}\right)$. The known NOS inhibitor L-NAME was used as reference compound. 
Reduction of nitrate to nitrite and determination of nitrite: the Griess-assay

In order to measure the effect of LPS on total nitrite/ nitrate formation as well as the inhibition by L-NAME, oxymetazoline and xylometazoline on the LPS effect, cells were incubated for $24 \mathrm{~h}$ with LPS and in the absence and presence of the test compounds in final concentrations varying between $10^{-5} \mathrm{M}$ and $10^{-3} \mathrm{M}$. An aliquot of $150 \mu \mathrm{L}$ of the cell suspension was deproteinated by adding $20 \mu \mathrm{L}$ $\mathrm{NaOH}(1 \mathrm{M})$ and $20 \mu \mathrm{LnSO}_{4}(1 \mathrm{M})$. After shaking firmly the incubations were left on ice for $5 \mathrm{~min}$ and centrifuged (5 min, 1,500 $\times g$ at $4^{\circ} \mathrm{C}$, Heraeus Christ, Biofuge A). For the conversion of nitrate to nitrite $K$. Pneumoniae (1.4 $\mathrm{mg} \cdot \mathrm{mL}^{-1}$ in $50 \mathrm{mM}$ PBS, $\mathrm{pH}=7.4$ ) was mixed with 2 volumes of $0.2 \mathrm{M}$ TES $(\mathrm{pH}=7.0)$ and 2 volumes of $0.5 \mathrm{M}$ sodium formate. Of this mixture, $50 \mu \mathrm{L}$ was added to 100 $\mu \mathrm{L}$ of the deproteinated sample. Nitrate reduction was performed at room temperature in a vacuum desiccator containing a dish of water to reduce evaporation of the reaction mixtures. After $30 \mathrm{~min}$ the tubes were removed and $0.5 \mathrm{ml}$ of nitrogen flushed water was added. After centrifugation $\left(5 \mathrm{~min}, 15,000 \times g\right.$ at $\left.4^{\circ} \mathrm{C}\right) 0.5 \mathrm{~mL}$ of the incubate mixture was added to $50 \mu \mathrm{L}$ of sulphanyl amide $\left(1 \%\right.$ in $\left.5 \% \mathrm{H}_{3} \mathrm{PO}_{4}\right)$ and the tubes were placed at $4{ }^{\circ} \mathrm{C}$ for 10 min. After this incubation $50 \mu \mathrm{L}$ of $0.1 \%$ weight/volume (w/v) $N$-(1-naphtyl) ethylenediamine was added and within $30 \mathrm{~min}$ the absorption of nitrite was determined at $540 \mathrm{~nm}$ in a Packard Argus 400 microplate reader. Standards containing $0-150 \mu \mathrm{M} \mathrm{NaNO}_{2}$ and $\mathrm{NaNO}_{3}$ were used for quantification.

\section{Determination inhibition of nitric oxide synthase acti-} vity: ${ }^{3}$ H-citrulline assay

In order to separate the effects of the test compounds on induction of iNOS and on the enzymatic iNOS activity per $s e$, two different sets of experiments were performed. To establish the effect of the test compounds on iNOS induction, a $24 \mathrm{~h}$ incubation of the N8383 cells with LPS was performed in the presence of test compounds. After the 24 $\mathrm{h}$ incubation period the test compounds were removed by washing. To establish the effect of the test compounds on iNOS enzymatic activity, cells were preincubated for $24 \mathrm{~h}$ with LPS in the absence of test compounds. These were only added during the conversion of L-arginine to L-citrulline in the ${ }^{3} \mathrm{H}$-citrulline assay.

After incubation with LPS, with or without test compounds $\left(10^{-4}\right.$ to $\left.10^{-3} \mathrm{M}\right), \mathrm{N} 8383$ cells were collected and resuspended at a cell concentration of $10^{7} \mathrm{cell} \cdot \mathrm{mL}^{-1}$ in Tris/ $\mathrm{HCl}$-buffer $\left(50 \mathrm{mM}, \mathrm{pH}=7.4\right.$ at $\left.4^{\circ} \mathrm{C}\right)$ containing $2 \mu \mathrm{M}$ leupeptin, $1 \mathrm{mM}$ PMSF, $1 \mathrm{mM}$ dithiothreitol, $10 \mu \mathrm{g} \cdot \mathrm{mL}^{-1}$ trypsin inhibitor from soybean, $2 \mu \mathrm{g} \cdot \mathrm{mL}^{-1}$ aprotinin, 0.1 $\mathrm{mM}$ EDTA and $230 \mathrm{mM}$ sucrose. The cell suspension was subsequently sonicated for $5 \mathrm{~min}$ at $4^{\circ} \mathrm{C}$. Of the obtained cell suspension $40 \mu \mathrm{L}$ was added to $60 \mu \mathrm{L}$ of a Tris HClbuffer $\left(50 \mathrm{mM}, \mathrm{pH}=7.4\right.$ at $\left.37^{\circ} \mathrm{C}\right)$ containing $1 \mathrm{mM}$ NADPH, $10 \mu \mathrm{M}$ L-arginine and $20 \mathrm{nCi}\left[{ }^{3} \mathrm{H}\right]$-L-arginine (specific activity; $63 \mathrm{Ci} \cdot \mathrm{mmol}^{-1}$ ). For measuring the enzymatic inhibition test compounds were added in a concentration of $10^{-4}$ to $10^{-3} \mathrm{M}$. Activity of iNOS was measured in the presence of $1 \mathrm{mM}$ EGTA, whereas cNOS activity was determined using $2 \mathrm{mM} \mathrm{CaCl}$. Nonenzymatic conversion was determined by heating the cell suspension $\left(100^{\circ} \mathrm{C}\right.$ for $\left.2 \mathrm{~min}\right)$. Both cNOS activity and nonenzymatic conversion were not found. The reaction was carried out for $45 \mathrm{~min}$ at $37^{\circ} \mathrm{C}$ and terminated by adding $1 \mathrm{ml}$ of icecold Hepes-buffer $\left(20 \mathrm{mM}, \mathrm{pH}=5.5\right.$ at $\left.4^{\circ} \mathrm{C}\right)$ and putting the vials on ice. L-arginine was removed from the reaction mixture by adding $1 \mathrm{~mL}$ of the ion-exchanger Dowex $\left(\mathrm{H}_{2} \mathrm{O}\right.$ / Dowex-50W, 1:1, $\mathrm{Na}^{+}$-form, 200-400 mesh, 8\% crosslinks, $\mathrm{pH}=7.0)$ and shaking firmly. After centrifugation (15 $\min , 2,100 \times g$ at $4{ }^{\circ} \mathrm{C}$ ) the reaction product $\left[{ }^{3} \mathrm{H}\right]$-L-citrulline was measured by transferring $1 \mathrm{~mL}$ of the supernatant to scintillation vials containing $4 \mathrm{~mL}$ Packard Ultima Gold scintillation fluid. Radioactivity was counted in a Packard Tri-carb (1900 CA) liquid scintillation analyzer. All samples were corrected for background radioactivity.

The same ${ }^{3} \mathrm{H}$-citrulline assay was used to determine the possible inhibitory effects of oxymetazoline and xylometazoline (concentrations between $10^{-4} \mathrm{M}-3 \times 10^{-3} \mathrm{M}$ ) on cNOS activity. In these experiments enzymatic activity was measured in the presence of $2 \mathrm{mM} \mathrm{CaCl}^{2}$. L-NAME was used as reference compound. However, these measurements were performed in synaptosomes obtained from the cerebella of male Wistar rats as these cells are known to contain high levels of cNOS. Activity of iNOS could not be detected in this tissue as was shown by using a calcium free buffer.

\section{Determination of cell viability}

In the experiments in which the alveolar cell line, NR 8383 , was used, the viability of the cells was tested at different stages of the experiments using thrypan blue. When more than $5 \%$ of the cells in a sample were stained with thrypan blue the samples was no longer viable and therefore disregarded.

\section{Determination of nitric oxide scavenging}

Possible NO-scavenging properties of both compounds were investigated by using a amperometric NO-sensor [24]. As a reference compound the well known NO scavenger haemoglobin was used. Two microlitres of NOspiked deoxygenated water was added to $20 \mathrm{~mL}$ of 50 $\mathrm{mM}$ phosphate buffer $(\mathrm{pH}=7.4)$ in a thermostated vessel $\left(37^{\circ} \mathrm{C}\right)$. The vessel was kept under a $\mathrm{N}_{2}$ atmosphere. The decrease in NO concentration with time was measured with an Iso-NO meter (World Precision instruments, Sarasota FL, USA) coupled to both a MacLab ${ }^{\mathrm{TM}}$ interface (ML020 MacLab/8; AdInstruments, London, UK) on an Apple Macintosh computer with "Chart" software and a chart recorder (Kipp, Delft, the Netherlands) in the presence and absence of the test compounds oxymetazoline and xylometazoline (final concentrations up to $10^{-3} \mathrm{M}$ ) and reference compound (final concentrations used were $3.9 \times 10^{-7}$ and $7.8 \times 10^{-7}$ ) in solution. During this procedure the reaction mixture was mixed using a magnetic stirrer. 


\section{Results}

Determination of inhibition of inducible nitric oxide synthase activity

Nitrite formation after lipopolysaccharide stimulation. The effects of L-NAME, oxymetazoline and xylometazoline on the production of nitrite and nitrate, which are formed after oxidation of the unstable NO, were determined in the Griess-assay. The amount of nitrite measured after nitrate reduction, reflects the iNOS activity.

Nitrite formation could only be measured in LPS induced cells. When no test compound was added the LPS induced cells gave a mean total nitite concentration of $117 \pm 12 \mu \mathrm{M}$. All data concerning iNOS are presented as the fraction of this value.

All compounds showed a dose dependent inhibitory effect on the nitrite formation (fig. 2). In contrast to LNAME, oxymetazoline and xylometazoline showed no inhibition of nitrite formation up to a concentration of $10^{-4} \mathrm{M}$, whereas at this concentration L-NAME gave $25 \%$ inhibition. However, oxymetazoline and xylometazoline inhibited the nitrite formation completely at a concentration of $1 \mathrm{mM}$ whereas L-NAME only inhibited $\sim 60 \%$. To exclude possible inhibition of cell growth or reaction with components of the Griess-assay by the compounds, control experiments were performed. None of these confounding reactions occurred.

Citrulline formation after lipopolysaccharide stimulation in the presence of test compounds

To elucidate the mode of action of this inhibitory effect, the compounds were investigated in the ${ }^{3} \mathrm{H}$-citrulline assay in which the effect of the compounds on iNOS induction and enzymatic iNOS activity could be separated. Lcitrulline is formed from L-arginine by NOS under the production of NO. The amount of L-citrulline production reflects the enzymatic activity of NOS.

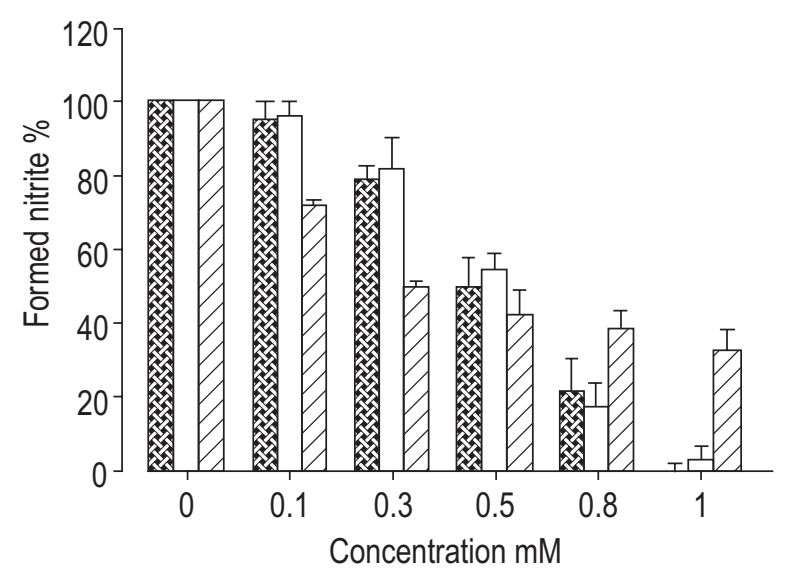

Fig. 2. - The overall inhibitory effect of oxymetazoline (雄) and xylometazoline $(\square)$ on inducible nitric oxide (NO) synthase was investigated by measuring nitrite production in the Griess assay. Lnitroarginine methyl ester (L-NAME) $(\mathbb{C})$ was used as a reference compound. The inhibition of nitrite formation was concentration dependent for all compounds. At a concentration of $1 \mathrm{mM}$ total inhibition of NO production was shown for oxymetazoline and xylometazoline. LNAME, on the other hand, only inhibited nitrite production for $\sim 60 \%$.
When cells were not stimulated with LPS, no L-citrulline could be detected. The baseline radioactivity value of the formed ${ }^{3} \mathrm{H}$-citrulline was determined in LPS induced cells to which no test compound was added. The inhibition by the test compounds is presented as a fraction of the LPS induced value.

Different concentrations of L-NAME, oxymetazoline and xylometazoline were present during LPS induced iNOS induction for $24 \mathrm{~h}$ and then removed by washing. Oxymetazoline and xylometazoline showed a prominent dose dependent reduction of L-citrulline formation (fig. 3). More than $50 \%$ inhibition of L-citrulline formation was obtained for both compounds at a concentration of 0.3 $\mathrm{mM}$, whereas complete inhibition for both compounds was obtained at $1 \mathrm{mM}$. L-NAME also showed some reduction however, at a concentration of $1 \mathrm{mM}$ only $50 \%$ reduction was found.

Citrulline formation after lipopolysaccharide stimulation in the absence of test compounds: inhibition of enzymatic inducible nitric oxide synthase activity

When cells were not stimulated with LPS, L-citrulline could not be detected. The baseline radioactivity value of the formed ${ }^{3} \mathrm{H}$-citrulline was determined in LPS induced cells to which no test compound was added. The inhibition by the test compounds is presented as a fraction of the LPS induced value.

Oxymetazoline and xylometazoline showed a moderate concentration dependent inhibitory effect on the LPS stimulated iNOS activity (fig. 4). At a concentration of 1 $\mathrm{mM}$, added after $24 \mathrm{~h}$ of LPS stimulation, both compounds inhibited iNOS activity $\sim 50 \%$, whereas L-NAME inhibited almost completely (85\%) even when used at a concentration 10 times lower. The test compounds did not influence the separation of ${ }^{3} \mathrm{H}$-citrulline and ${ }^{3} \mathrm{H}$-arginine.

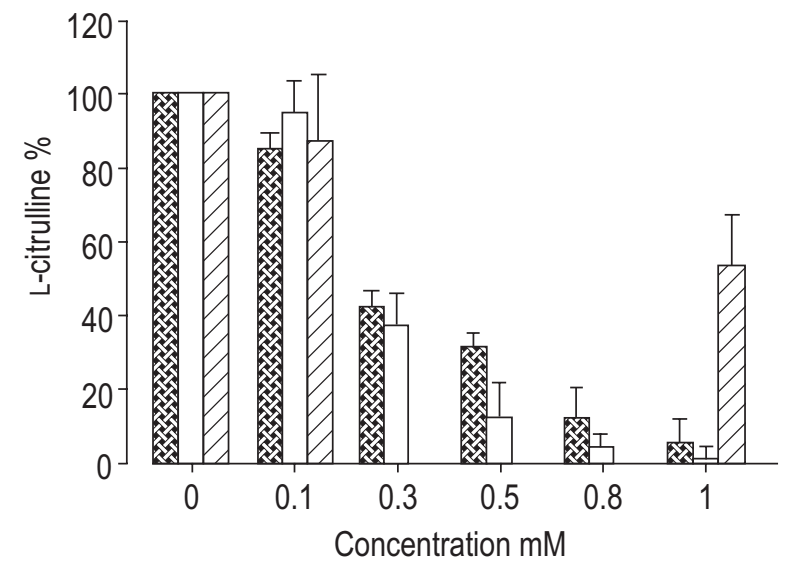

Fig. 3. - The inhibitory effect of oxymetazoline (掣) and xylometazoline $(\square)$ on the lipopolysaccharide (LPS) induced inducible nitric oxide synthase (iNOS) induction measured by the formation of $\mathrm{L}-$ citrulline using the ${ }^{3} \mathrm{H}$-citrulline assay. L-nitroarginine methyl ester (LNAME) $(\mathbb{Z})$ was used as a reference compound. In contrast to L-NAME a strong concentration dependent reduction of $\mathrm{L}$-citrulline formation was seen for oxymetazoline and xylometazoline, which completely inhibited iNOS induction at a concentration of $1 \mathrm{mM}$. At this concentration LNAME only gave $50 \%$ inhibition. 
Determination of the inhibition of constitutive nitric oxide synthase

The baseline radioactivity value of the formed ${ }^{3} \mathrm{H}-$ citrulline was determined in samples to which no test compound was added. The data are presented as fractions of the absolute baseline values.

The inhibition of cNOS activity in rat brain tissue by oxymetazoline and xylometazoline was concentration dependent and in the same order of magnitude as inhibition of enzymatic iNOS activity measured by the ${ }^{3} \mathrm{H}$-citrulline assay. At a concentration of $1 \mathrm{mM}$ oxymetazoline and xylometazoline inhibited L-citrulline formation by $50 \%$ and $65 \%$ respectively (fig. 5). The inhibition activity of LNAME, was as expected, much more prominent. At a concentration of $0.3 \mu \mathrm{M}$ already $50 \%$ of cNOS activity was inhibited (data not shown).

\section{Determination of nitric oxide radical scavenging}

In contrast to the reference haemoglobin, which showed potent scavenging, no scavenging of NO radicals occurred by either oxymetazoline or xylometazoline added to the reaction mixture at final concentrations up to $10^{-3} \mathrm{M}$.

\section{Discussion}

The effects of the nasal decongestants oxymetazoline and xylometazoline on the induction and activity of iNOS and the activity of cNOS were investigated. NOS activity is of importance in inflammatory disorders of the upper respiratory tract via at least two mechanisms. Firstly the regulation of nasal vascular tone is thought to be under cNOS control $[14,16,25]$ and secondly iNOS is important in the modulation of the inflammatory and immunological response [18]. As high doses of oxymetazoline and xylo-

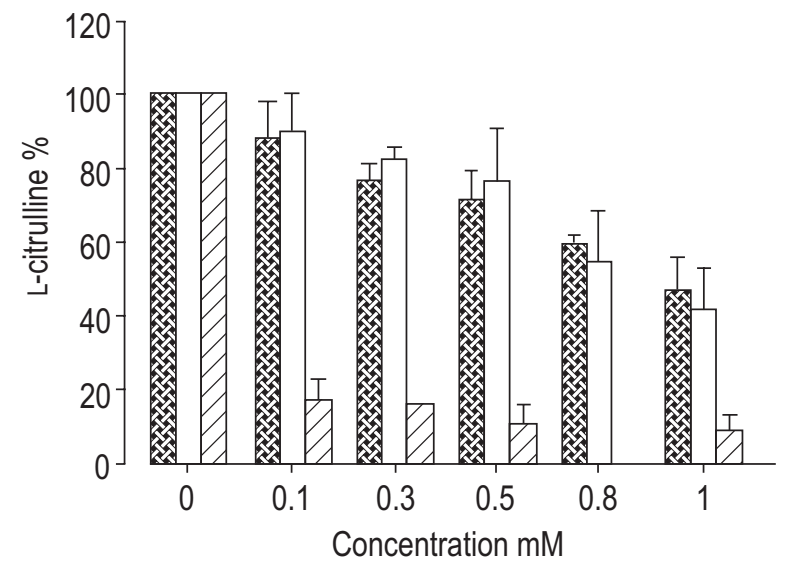

Fig. 4. - The inhibitory effect of oxymetazoline (爻) and xylometazoline ( $\square$ ) on the enzymatic inducible nitric oxide synthase (iNOS) activity measured by formation of L-citrulline using the ${ }^{3} \mathrm{H}$ citrulline assay. L-nitroarginine methy ester (L-NAME) $(\mathbb{Z})$ was used as reference compound. Compounds were only added to the reaction mixture during incubation with L-arginine. A moderate concentration dependent reduction in L-citrulline formation was seen for oxymetazoline and xylometazoline. In contrast to L-NAME, which gave prominent inhibition of enzymatic iNOS activity at a concentration of $10^{-4}$, oxymetazoline and xylometazoline inhibited L-citrulline formation $\sim 50 \%$ at a concentration of $10^{-3} \mathrm{M}$. metazoline are frequently used in the topical treatment of upper respiratory tract inflammation, the effect of these compounds on NO regulation is of interest.

LPS was used to induce iNOS in a macrophage cell line. The false substrate for NOS, L-NAME, as measured by the nitrite/nitrate formation, decreased the amount of NO metabolites dose dependently, although not completely. Since oxymetazoline and xylometazoline in the same concentration were capable of complete inhibition of iNOS, this finding suggests at least an additional mode of pharmacological action of these compounds. It should be noted that in the nitrite/nitrate experiments NO was formed as an intermediate and that the inhibitory effects on NOS could be due to scavenging of NO by the used test compounds. To exclude this, the test compounds were investigated for possible NO scavenging properties. No NO scavenging occurred.

Decreased NO formation could be explained by either, the inhibition of enzymatic activity or the inhibition of induction, hence these were investigated separately. Oxymetazoline and xylometazoline were not full inhibitors of both iNOS and cNOS activity, measured by ${ }^{3} \mathrm{H}$-citrulline formation. This is in contrast to L-NAME, which showed complete enzymatic inhibition of NOS, which is in accordance with the literature [26]. It is suggested that the incomplete enzymatic inhibition of both iNOS and cNOS by oxymetazoline and xylometazoline may be due to binding of the imidazoline part of these compounds to the haem domain of NOS. This mode of action is comparable but less efficient than for arginine derivatives such as LNAME [27]. In this way it was proven that the inhibitory effect of oxymetazoline and xylometazoline could not be fully explained by enzyme inhibition. Inhibition of induction of the iNOS enzyme might therefore be involved as well. This was investigated in an experiment in which iNOS enzyme activity was measured after washing away the test compounds, i.e. the test compounds were present during LPS induction of iNOS. Both compounds, in

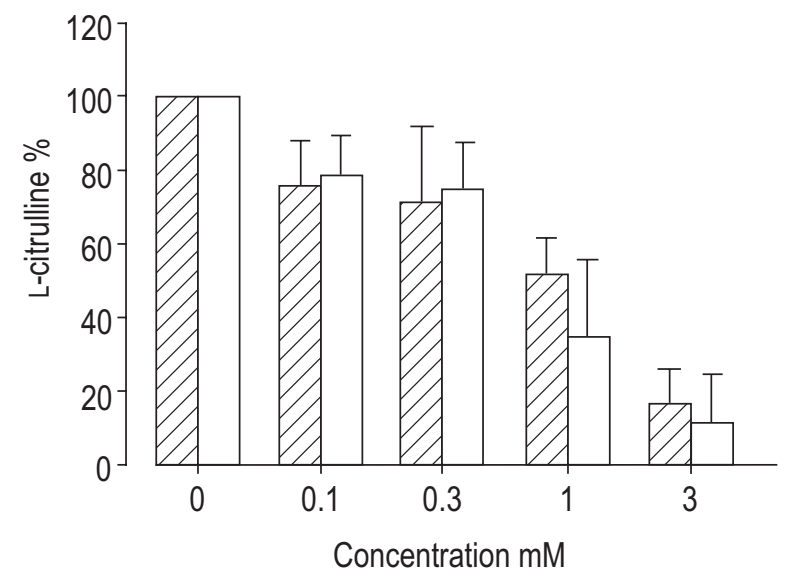

Fig. 5. - The inhibitory effect of oxymetazoline $(\mathbb{Z})$ and xylometazoline $(\square)$ on the enzymatic activity of constitutive nitric oxide synthase (cNOS) measuring L-citrulline formation using the ${ }^{3} \mathrm{H}$ citrulline assay. The L-citrulline production was concentration dependent diminished by both compounds. At a concentration of $10^{-3} \mathrm{M}$ oxymetazoline inhibited cNOS by $50 \%$ and xylometazoline by $65 \%$. The effects of both compounds on the enzymatic activity of cNOS are comparable to their effects on the enzymatic activity of inducible nitric oxide synthase. 
contrast to L-NAME, completely inhibited spontaneous iNOS activity and thus expression of iNOS.

It is known that the induction of iNOS is regulated by transcription factors, of which the most important is nuclear factor- $\kappa \mathrm{B}(\mathrm{NF}-\kappa \mathrm{B})$ [28]. As NF- $\mathrm{BB}$ in cells is activated by many factors such as micro-organisms, oxidants, antigens and LPS [29] a possible site of action of oxymetazoline and xylometazoline may be the inhibition of the activation of NF- $\kappa$ B. The nasal mucosa has an important function in preparing the inspired air before entering the lungs through filtering particles and regulating humidity and temperature. NO seems to play a pivotal role in these physiological functions as amongst others it has been shown that NO is involved in the regulation of the vascular tone in the nasal mucosa $[25$, $30]$. By this means $\mathrm{NO}$ is thought to modulate nasal vascular conductance and nasal cavity volume, which are correlated to the nasal airway resistance $[16,17]$. It should be noted however, that recent investigations, using high flow rate insufflation, contradict the existence of such a relationship [31, 32]. The difference in these results is thought to be due to underestimation of measured NO outputs as low flows were used instead of higher and probably more physiological transnasal airflows [33]. Another possibility is that this discrepancy might be explained by the fact that NO levels measured in nasal air, which are predominantly produced by a $\mathrm{Ca}^{2+}$ independent form of NOS in epithelial cells in the paranasal sinuses $[34,35]$ are not responsible for vascular tone regulation, which may be predominantly under control of nasal vascular epithelial cNOS. This speculation might be supported by the finding that lidocain showed strong inhibition of sinus NO production in contrast to nasal NO production [36].

Furthermore, it has been shown that human nasal mast cells, next to alpha adrenoceptor effects, play a major role in the regulation of the blood supply to the nasal mucosa. They contain a particulate isoform of NOS, which besides other vasoactive substances, may effect the congestive state of the nasal mucosa [37]. In addition, nasal exudation, of importance in nasal inflammation, also seems to be mediated by NO via increase of the vascular permeability [38]. NO, generated via iNOS, which is induced in inflammatory cells and epithelium of the upper respiratory tract, is an important mediator in modulating the inflammatory and immunological response [18, 39]. Involvement of NO was shown for rhinitis based on house dust mite allergy [13], seasonal rhinitis [11], chronic rhinitis [15] and nasal polyps [14]. NO levels are high in exhaled air, which was shown to be originating mainly from the nasal and paranasal airways [34, 40-42]. These high concentrations of the reactive NO may contribute to aggravating airway inflammation, which has been shown after, for example, viral airway infection [43]. The involvement of iNOS may be supported by the finding that glucocorticoids, which amongst others inhibit the induction of iNOS and have beneficial effects in treating airway inflammation, inhibit the increase in exhaled NO in asthmatic patients [44].

All of the previously mentioned studies indicate that NO has a role in upper respiratory tract inflammation. This role may be influenced by nasal decongestants like oxymetazoline and xylometazoline. Although, the role of nasal NO in nasal vascular regulation is not clearly established most



Fig. 6. - Characteristic example of a scavenging experiment. Time dependent degradation of nitric oxide (NO) in buffer in the presence of a possible scavenger. A concentration of $1 \mathrm{mM}$ of both test compounds did not enhance the degradation of measured NO with time, indicating that scavenging of NO did not occur. In contrast to the decongestive compounds (oxymetazoline/xylometazoline; - - ) the reference compound haemoglobin $(---)\left(7.8 \times 10^{-7}\right)$ showed potent time dependent NO degradation. Vertical arrow shows addition of the scavenging test compound.

studies support the observation that administration of nasal decongestants significantly decreases nasal NO concentration $[30,31]$. The mechanism by which decongestants reduce NO concentration is not known. It was speculated to be due to vasoconstriction of the nasal venous sinusoids, which may lead to a decreased epithelial surface area and affect the NO diffusion into the lumen of the nasal cavity [45]. It may also be related to the reduction of bloodflow leading to a diminished availability of substrates for NOS or by a toxic effect of the decongestant in the chain of reactions that produces NO [31]. Until now a specific site of action could not be ascertained.

In the present study this mode of action was elucidated as a direct inhibitory effect on enzymatic activity of cNOS and iNOS, but especially induction of iNOS was shown. In addition, no direct scavenging effect of either compound could be found.

The results were obtained in rat alveolar macrophages as these cell lines are a reliable source of iNOS [22, 23]. Differences in the NOS systems have been found between cell types of animals of different species and humans [9]. Therefore, the results cannot be directly extrapolated to human upper airways. However, although this is an in vitro model the results may contribute to the understanding of NO in upper respiratory tract pathophysiology and the influence of nasal decongestants herein. Presuming that the NO generating system plays a role in the pathogenesis of upper respiratory tract inflammations, the findings may suggest an additional beneficial effect of the nasal decongestants oxymetazoline and xylometazoline in the topical treatment of these disorders. It should be noted, however, that these compounds, at least in their pharmaceutical matrix, also have unfavourable effects on nasal mucosa like decreasing mucociliary clearance [46, 47], and inducing rhinitis medicamentosa [48].

In conclusion, the studies mentioned above imply that constitutive nitric oxide synthase activity serves beneficial physiological functions in the nose, whereas an exaggerated inducible nitric oxide synthase activity, which is induced by overexpression, causes an exacerbation of the 
inflammatory process. Possible treatment via nitric oxide mechanisms should therefore primarily focus on inhibition of inducible nitric oxide synthase alone, leaving the necessary physiological control via constitutive nitric oxide synthase intact. In an in vitro model oxymetazoline and xylometazoline showed only moderate effects as direct inhibitors of the nitric oxide-producing enzymes. However, these compounds, used in their clinically applied concentration, are able to inhibit the induction of inducible nitric oxide synthase completely, which renders them selective tools for attenuation of inducible nitric oxide synthase activity, a mode of action which has not been described before.

\section{References}

1. Furchgott RF, Zawadski JV. The obligatory role of endothelial cells in the relaxation of arterial smooth muscle by acetylcholine. Nature 1980; 288: 373-376.

2. Ignarro LJ, Buga GM, Wood KS, Byrns RE, Chaudhury G. Endothelium-derived relaxing factor produced and released from artery and vein is nitric oxide. Proc Natl Acad Sci USA 1987; 84: 9265-9269.

3. Marletta MA, Yoon PS, Iyengar R, Leaf CD, Wishnor JS. Macrophage oxidation of L-arginine to nitrite and nitrate: Nitric oxide is an intermediate. Biochemistry 1988; 27: 8706-8711.

4. Hibbs JB Jr, Taintor RR, Vavrin Z, Rachlin EM. Nitric oxide: a cytotoxic activated macrophage effector molecule. Biochem Biophys Res Commun 1988; 157: 87-94.

5. Radomski MW, Palmer RMJ, Moncada S. Endogenous nitric oxide inhibits human platelet adhesion in vascular endothelium. Lancet 1987; 2: 1037-1038.

6. Knowles RG, Palacios M, Palmer RMJ, Moncada S. Formation of nitric oxide from L-arginine in the central nervous system: a transduction mechanism for stimulation of the soluble guanylate cyclase. Proc Natl Acad Sci USA 1989; 86: 5159-5162.

7. Bredt DS, Glatt CE, Fotuhi M, Dawson TM, Snyder SH. Nitric oxide synthase protein and mRNA are discretely localized in neuronal populations of the mammalian CNS together with NADPH diaphorase. Neuron 1991; 7: 615624.

8. Moncada S, Palmer RMJ, Higgs EH. Nitric oxide: physiology, pathophysiology, and pharmacology. Pharm Rev 1991; 43: 109-142.

9. Knowles RG, Moncada S. Nitric oxide synthases in mammals. Biochem J 1994; 298: 249-258.

10. Kharitonov SA, Yates D, Barnes PJ. Increased nitric oxide in exhaled air of normal human subjects with upper airway respiratory tract infections. Eur Resp $J$ 1995; 8: 295-297.

11. Martin U, Bryden K, Devoy M, Howarth P. Increased levels of exhaled nitric oxide during nasal and oral breading in subjects with seasonal rhinitis. J Allergy Clin Immunol 1996; 97: 768-772.

12. Garrelds IM, Amsterdam van JCG, De Graaf-in't Veld C, Gerth van Wijk R, Zijlstra FJ. Nitric oxide metabolites in nasal lavage fluid of patients with house dust mite allergy. Thorax 1995; 50: 275-279.

13. Ramis I, Lorente J, Rosello-Catafau J, Quesada P, Gelpi E, Bulbena O. Differential activity of nitric oxide synthase in human nasal mucosa and polyps. Eur Respir $J$ 1996; 9: 202-206.

14. Furakawa K, Harrison DG, Saleh D, Shennib H, Chagnon
FP, Giaid A. Expression of nitric oxide synthase in the human nasal mucosa. Am J Respir Crit Care Med 1996; 153: 847-850.

15. Rosbe KW, Mims JW, Prazma J, Petrusz P, Rose A, Drake AF. Immunohistochemical localisation of nitric oxide synthase activity in upper respiratory epithelium. Laryngoscope 1996; 106: 1075-1079.

16. Rinder J, Lundberg JM. Nasal vasoconstriction and decongestant effects of nitric oxide synthase in the pig. Acta Physiol Scand 1996; 157: 233-244.

17. Imada I, Iwamoto J, Nonaka S, Kobayashi Y, Unno T. Measurement of nitric oxide in human nasal airway. Eur Respir J 1996; 9: 556-559.

18. Albina JE, Reichner JS. Nitric oxide in inflammation and immunity. New Horizons 1995; 3: 46-64.

19. Westerveld GJ, Scheeren RA, Dekker I, Griffioen DH, Voss H-P, Bast A. Antioxidant levels of oxymetazoline and xylometazoline. Eur J Pharmacol 1995; 291: 27-31.

20. Phizackerly PJR, Al-Dabbagh SA. The estimation of nitrate and nitrite in saliva and urine. Anal Biochem 1983; 131: 242-245.

21. Bredt DS, Snyder SH. Isolation of nitric oxide synthase, a calmodulin-requiring enzyme. Proc Natl Acad Sci USA 1990; 87: 682-685.

22. Helmke RJ, Boyd RL, German VF, Mangos JA. From growth factor dependence to growth factor responsiveness: the genesis of an alveolar macrophage cell line. In Vitro Cell Development Biol 1987; 23: 567-574.

23. Helmke RJ, German VF, Mamgos JA. A continuous alveolar macrophage cell line: comparisons with freshly derived alveolar macrophages. In Vitro Cell Development Biol 1989; 25: 44-48.

24. Vriesman MF, Haenen GRMM, Westerveld GJ, Paquay JBG, Voss H-P, Bast A. A method for measuring nitric oxide radical scavenging activity. Scavenging properties of sulfur containing compounds. Pharmacy World \& Sci 1997; 19: 283-286.

25. Rinder J. Sensory neuropeptides and nitric oxide in nasal vascular regulation. Acta Physiol Scand 1996; 157: 7-45.

26. Mitchell JA, Kohlhaas KL, Sorrentino R, Warner TD, Murad F, Vane JR. Induction by endotoxin of nitric oxide synthase in the rat mesentery: lack of effect on action of vasoconstrictors. Br J Pharmacol 1993; 109: 265-270.

27. Peterson DA, Peterson DC, Archer S, Weir EK. The non specific nitric oxide inhibitors. Biochem Biophys Res 1992; 187: 797-801.

28. Xie Q-W, Kashiwabara Y, Nathan C. Role of transcription


Biol Chem 1994; 269: 4705-4708.

29. Barnes PJ, Karin M. Nuclear factor $\kappa B$ - A pivotal transcription factor in chronic inflammatory disease. $N$ Engl J Med 1997; 336: 1066-1071.

30. Rinder J, Lundberg JON, Anggard A, Alving K, Lundberg JM. Effects of topical nasal decongestants, Larginine and nitric oxide synthase inhibition, on nasal cavity nitric oxide levels and nasal cavity volume in man. Am J Rhinol 1996; 10: 399-408.

31. Chatkin JM, Djupesland PG, Qian W, et al. Nasal nitric oxide is independent of nasal cavity volume. Am J Rhinol 1999; 13: 179-184.

32. Silkoff PE, Chatkin J, Qian W, et al. Nasal nitric oxide: a comparison of measurement techniques. Am J Rhinol 1999; 13: 169-178.

33. Djuppesland PG, Chatkin JM, Qian W, et al. Aerodynamic influences on nasal nitric oxide output measurements. Acta Otolaryngol 1999; 119: 479-485.

34. Lundberg JON, Farkas-Szallasi T, Weitzberg E, et al. 
High nitric oxide production in human paranasal sinuses. Nature Med 1995; 1: 370-373.

35. Lundberg JON, Weitzberg E, Rinder J, et al. Calciumindependent and steroid-resistant nitric oxide synthase activity in human paranasal sinus mucosa. Eur Respir $J$ 1996; 9: 1344-1347.

36. Haight JS, Djupesland PG, Qian W, et al. Does nasal nitric oxide come from the sinuses? J Otolaryngol 1999; 28: 197-204.

37. Bacci S, Arbi-Riccardi R, Mayer B, Rumino C, BorghiCirri MB. Localisation of nitric oxide synthase immunoreactivity in mast cells of human nasal mucosa. Histochem 1994; 102: 89-92.

38. Lane AP, Prazma J, Baggett HC, Rose AS, Pillsbury HC. Nitric oxide is a mediator of neurogenic vascular exudation in the nose. Otolaryngol Head Neck Surg 1997; 116: 294-300.

39. Croen KD. Evidence for an antiviral effect of nitric oxide. J Clin Invest 1993; 91: 2446-2452.

40. Schedin U, Frostell C, Persson MG, Jakobsson J, Andersson $\mathrm{G}$, Gustafsson LE. Contribution from upper and lower airways to exhaled endogenous nitric oxide in humans. Acta Anaesthesiol Scand 1995; 39: 327-332.

41. Lundberg JON, Weitzberg E, Nordvall SL, Kuylenstierna $\mathrm{R}$, Lundberg JM, Alving K. Primarily nasal origin of exhaled nitric oxide and absence in Kartagener's syndrome. Eur Respir J 1994; 7: 1501-1504.

42. Kimberly B, Nejadnik B, Giraud GD, Holden WE. Nasal contribution to exhaled nitric oxide at rest and during breathholding in humans. Am J Respir Crit Care Med 1996; 153: 829-836.

43. Barnes PJ, Liew FY. Nitric oxide and asthmatic inflammation. Immunol Today 1995; 1: 128-130.

44. Kharitonov SA, Yates D, Robbins RA, Thomas PS, Barnes PJ. Corticosteroids decrease exhaled nitric oxide. Am J Respir Crit Care Med 1994; 149: A201.

45. Ferguson EA, Eccles R. Changes in nasal nitric oxide concentration associated with symptoms of common cold and treatment with a topical nasal decongestant. Acta Otolaryngol (Stockh) 1997; 117: 614-617.

46. Van de Donk HJM, Van den Heuvel AGM, Zuidema J, Merkus FWHM. The effect of nasal drops and their additives on human mucociliary clearance. Rhinology 1982; 20: 127-137.

47. Deitmer T, Scheffler R. The effects of different preparations of nasal decongestants on ciliary beat frequency in vitro. Rhinology 1993; 31: 151-153.

48. Graf PM, Hallen H. One year follow-up of patients with rhinitis medicamentosa after vasoconstrictor withdrawal. Am J Rhinol 1997; 11: 67-72. 